\title{
Characteristics, Similarities, And Differences Among Four- Year Cooperative Engineering Programs In The United States
}

Robert I. Egbert, Missouri State University, USA Lorene H. Stone, Missouri State University, USA David L. Adams, Missouri State University, USA

\begin{abstract}
Four-year cooperative engineering programs are becoming more common in the United States. Cooperative engineering programs typically involve a "parent" institution with an established engineering program and one or more "satellite" institutions which typically have few or no engineering programs and are located in an area where there are few, if any, other local opportunities for students to study engineering. In spite of an extensive literature search, the investigators were not able to find much information on these types of programs. Thus, in an effort to learn more about the characteristics of such cooperative programs, Program Directors from universities involved in four-year cooperative engineering programs were asked about the nature of their programs. The purpose of the research project was to learn about the different approaches used in developing and administering cooperative engineering programs, and to understand the strength and weaknesses of the different approaches. A web-based survey, consisting of 26 open-ended questions, was sent to Program Directors from eleven universities; seven responded to all or a portion the survey questions. The survey requested information on majors offered, enrollment, ABET accreditation, age and geographic distribution of students, administrative policies, tuition practices, and other such characteristics of each program. The findings show that most of these cooperative programs have been in existence less than ten years. All are ABET accredited or plan to seek ABET accreditation. Most of the programs offer majors only in Civil, Electrical, and/or Mechanical Engineering. Administrative structures and procedures were similar among all the programs with only minor differences. Although four-year cooperative engineering programs are a relatively new phenomena in engineering education, the number of such programs appears to be increasing. The investigators expected to find that the majority of students in these programs were non-traditional, part-time students, who were geographically bound to the area served by the cooperative engineering program. However, the survey results revealed that the majority of students in these programs are fulltime, traditional students, who live within 100 miles of the institution housing the program. The students apparently choose these programs to avoid the costs of room and board at the program's parent campus. The findings of this survey are believed to be the first such survey done on four-year cooperative engineering programs in the U.S. The results of this research may be helpful to universities planning to start a cooperative engineering program.
\end{abstract}

Keywords: Collaborative Engineering Programs; Joint Engineering Programs; Cooperative Engineering Programs

\section{INTRODUCTION}

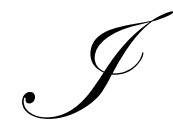

$\mathrm{n}$ recent years several different universities in the United States have developed four-year cooperative engineering education programs with one or more academic institutions. These programs are called various names, such as collaborative, joint, or cooperative programs. All such programs involve a "parent" institution, which typically has an established engineering program in several engineering disciplines, and one or more "satellite" institutions which typically have had few or no engineering programs and are located in an area where there are few, if any, other local opportunities for students to study engineering. 
The unique feature of this relatively new type of cooperative engineering program is that the parent and satellite institutions work together to offer a full four-year degree at the campus of the satellite institution. This usually involves courses taught by a combination of faculty from the parent and satellite institutions as well as some courses offered at the satellite campus via distance instruction from the parent institution.

These programs differ from the more traditional cooperative engineering programs, which are the so-called "two plus two" programs, also sometimes referred to as "pre-engineering" programs. In these programs the satellite institution signs a transfer agreement with the parent school which allows students enrolled at the satellite institution to take the first two, or in some cases three, years of engineering prerequisite classes, such as general education, chemistry, physics and mathematics courses, and then transfer to the parent institution for the remaining two years of engineering related coursework. Some satellite institutions may also offer a few of the basic introductory level engineering courses as part of their program. In the "two plus two" programs, students are awarded their engineering degree from the parent institution.

There appear to be three factors that lead to the establishment of cooperative engineering programs. The first factor is a desire by companies in the area who employ engineers to have an engineering education program in the region allowing them to recruit engineering graduates from the local area plus provide opportunities for their employees to pursue additional engineering education without leaving the area. The second factor is the presence of a local college or university with a desire to have an engineering program. The third factor is a demand for an engineering education program by local college age students.

The purpose of this study is to collect and report information on these newer, four-year cooperative engineering programs to determine if they share common characteristics and goals. The study attempts to identify the aspects of the programs that are unique or perhaps unexpected and to confirm one of the most common assumptions about such programs - namely that they are populated by non-traditional students who are place bound and without easy access to other engineering programs.

\section{LITERATURE REVIEW}

In spite of a rather extensive search, the authors were not able to find any previously published survey papers on four-year cooperative engineering programs. A few conference papers have described specific cooperative engineering programs. For example, Thamire and Ainane, 2002; Burbank, DeSain and Trajan, 2004; Wilson and Cambron, 2005; Hess et. al., 1996, among others describe their experience in establishing specific cooperative engineering programs between various institutions. However, no current research has attempted to examine and identify the distinctive characteristics of the total number of cooperative programs in the U.S.

\section{METHODOLOGY}

Program Directors of engineering programs at eleven U.S. universities/colleges identified as participating in a four-year cooperative engineering program were contacted and asked to participate in this web-based survey. Most of the schools in this sample are located in the Midwest, and a complete list of the targeted institutions (and their "parent" universities) is found in Appendix A.

The Center for Social Sciences and Public Policy Research (CSSPPR) at Missouri State University (MSU) was contracted to collect data for this study. The CSSPPR utilizes an up-to-date web-based computer system using Sensus software to create and administer on-line surveys and to work with respondent data. This system sends email messages to respondents (including pre- and post- questionnaire), as well as downloads data from the on-line surveys. A questionnaire, consisting of twenty-six open-ended items, was electronically sent to the Director of each of the identified cooperative engineering programs. A copy of the survey instrument is included in Appendix B. 


\section{FINDINGS}

Representatives from seven of the eleven cooperative engineering programs contacted responded to the survey for a response rate of $63.6 \%$. Several survey questions were not answered by one or more respondents and thus, the number of completed responses varies from question to question.

The specific survey responses are summarized below:

\section{Age Of Cooperative Programs}

As shown in Table 1, four-year cooperative engineering programs are a relatively recent trend in engineering education. The oldest reported program was established in the 1993-1994 academic year. However, most of the other programs in this study were started in the last ten years. An additional cooperative engineering program is scheduled to start classes in the 2010-2011 academic year.

Table 1: Age Of Four-Year Cooperative Engineering Programs

\begin{tabular}{|c|c|}
\hline Academic Year Established & Number of Programs \\
\hline $1993-1994$ & 1 \\
\hline $2000-2001$ & 1 \\
\hline $2001-2002$ & 2 \\
\hline $2008-2009$ & 1 \\
\hline $2009-2010$ & 1 \\
\hline $2010-2011$ & 1 \\
\hline
\end{tabular}

\section{Degrees Offered}

Table 2 shows the distribution of engineering majors offered on the satellite campuses for the programs surveyed. Note that these are all four-year B.S. degrees. All of the satellite programs offered a B.S. in Electrical Engineering, and all but two offered degrees in Civil or Mechanical Engineering. This is not an unexpected finding since these tend to be the most popular engineering degrees in most engineering schools.

Table 2: Engineering Degrees Offered At Satellite Programs

\begin{tabular}{|l|c|}
\hline \multicolumn{1}{|c|}{ Degree } & Number of programs \\
\hline Chemical Engineering & 1 \\
\hline Civil Engineering & 4 \\
\hline Computer Engineering & 1 \\
\hline Electrical Engineering & 5 \\
\hline Mechanical Engineering & 4 \\
\hline
\end{tabular}

\section{Enrollment}

Respondents were asked to report the total enrollment in the satellite programs over the past three academic years. Figures for the four programs that responded to this question are shown in Table 3.

Table 3: Enrollments In Satellite Engineering Programs

\begin{tabular}{|c|c|c|c|}
\hline Satellite Program & 2006-2007 Academic Year & 2007-2008 Academic Year & 2008-2009 Academic Year \\
\hline A & 221 & 220 & 232 \\
\hline B & 285 & 306 & 308 \\
\hline C & 35 & 28 & 25 \\
\hline D & N/A & N/A & 42 \\
\hline
\end{tabular}

${ }^{*}$ Program started in 2008-2009 academic year

${ }^{* *}$ No response $=3$ 
Programs ranged in size from small enrollment to over 300 students. The largest reported enrollment in satellite engineering programs was 308 students. Several of the programs are still relatively new or have just started classes for the first time in the 2010-2011 academic year; it is difficult to predict future enrollment trends in these programs.

\section{Student Characteristics}

Traditional Vs. Non-Traditional Students

Representatives from the satellite programs were asked to provide an estimate of the percentage of traditional students and non-traditional students in their program. For the purpose of this study, traditional students were defined as students who range in age from 18-22 years and who typically have not attended college before. The data related to traditional versus non-traditional student enrollment in these programs is shown in Table 4 .

Table 4: Percentage Of Traditional Student Enrollment

\begin{tabular}{|c|c|}
\hline Program & Traditional Student Enrollment (\%) \\
\hline A & 90 \\
\hline C & 90 \\
\hline D & 80 \\
\hline E & 100 \\
\hline
\end{tabular}

No response $=3$

While one perceived benefit of four-year cooperative programs is to make engineering education opportunities more accessible to a wider range of students, this study finds that most students in these programs are traditional college students. Non-traditional student enrollments in the surveyed programs were $20 \%$ or less.

\section{Full-Time Students Versus Part-Time Students}

Respondents were asked to provide an estimate of the percentage of both full-time and part-time students in their program. For the purpose of this survey a full-time student was identified as one taking twelve or more credits hours per semester or an equivalent amount per quarter. The data related to part-time versus full-time student enrollment in these programs is shown in Table 5.

Table 5: Percentage Of Full-Time Students

\begin{tabular}{|c|c|}
\hline Program & Full-Time Students (\%) \\
\hline A & 85 \\
\hline C & 95 \\
\hline D & 90 \\
\hline E & 100 \\
\hline
\end{tabular}

${ }^{*}$ No response $=3$

For the programs reporting data, the vast majority of students enrolled in cooperative engineering programs are full-time students. This is another unexpected finding, since it is commonly assumed that students enrolled in satellite programs are part-time students who work full-time while pursuing an engineering degree.

\section{Percentage Of Students In The Satellite Programs Living In Close Proximity To Campus}

The next question asked the Program Directors to provide an estimate of the percentage of students that resided both within a 50- and a 100- mile radius of the campus. The data related to this is presented in Table 6 . 
Table 6: Percentage Of Students Living Within 50 And 100 Miles Of The Satellite Campus

\begin{tabular}{|c|c|c|}
\hline Program & Reside Within 50 Miles (\%) & Reside Within 100 Miles (\%) \\
\hline A & 80 & 93 \\
\hline B & 99 & 100 \\
\hline C & 95 & 95 \\
\hline D & 80 & 80 \\
\hline E & 50 & 50 \\
\hline
\end{tabular}

No response $=2$

It is also commonly assumed that students enrolled in cooperative engineering programs are geographically bound, i.e., they are unable or unwilling to attend engineering programs at the parent institutions due to distance. This study confirms this assumption since the majority of students from the five responding programs reside within a 50-mile radius of the satellite campus.

\section{Percentage Of Students Remaining Within A 50 And/Or 100 Mile Radius Of The Satellite Campus After Graduation}

Each program representative was asked to provide an estimate of the percentage of their students who remain within 50 and/or 100 miles of the campus after graduating. Although only two of the satellite programs currently have graduates, the data from these programs, as shown in Table 7 , is interesting.

Table 7: Percentage Of Graduates Remaining Within 50 And 100 Miles Of The Satellite Program Campus

\begin{tabular}{|c|c|c|}
\hline Program & Graduates Within 50 Miles (\%) & Graduates Within 100 Miles (\%) \\
\hline A & 85 & 95 \\
\hline B & 80 to 90 & 90 \\
\hline
\end{tabular}

In both cases, the vast majority of the graduates remain in close proximity to the satellite campus. They are not moving away from the area in search of employment. Both of these programs are located in metropolitan areas and due to this, graduates do not need to move far to find desirable employment in their chosen field of engineering. This data could change significantly as more of the cooperative engineering programs begin to graduate their students. This will be an important area for further study.

Percentage Of Students In The Satellite Programs Who Are Pursuing A Second Degree After Obtaining A Previous Degree In A Non-Engineering Field

There has been some thought that students enrolled in cooperative engineering programs might be pursuing a second degree after receiving a first degree in a non-engineering field. Two of the satellite programs in this study indicated that there were students in their programs that had previous degrees in a non-engineering discipline. The percentage of second degree students is shown in Table 8.

Table 8: Percentage Of Students Pursuing An Engineering Degree After Receiving A First Degree In A Non-Engineering Discipline

\begin{tabular}{|c|c|}
\hline Program & Second Degree Students (\%) \\
\hline A & 4 \\
\hline C & 30 \\
\hline
\end{tabular}

No response $=5$

With the exception of one cooperative program, the percentage of students who are pursuing an engineering degree after receiving a first degree in a non-engineering field is small. This finding also reflects the fact that most of the students in these programs are of traditional age for college students. 
Percentage Of Students In The Satellite Programs Who Are Pursuing A Second Degree After Obtaining A Previous Engineering Degree

Survey respondents were asked to report the number of students in their programs who are pursuing a second degree in engineering after receiving a previous engineering degree. Only one of the satellite programs reported having students with a previous engineering degree enrolled in their program. These students are international students with engineering degrees from their home countries and are not a significant portion of the total enrollment in cooperative engineering programs in the U.S.

\section{Administrative Policies And Procedures}

\section{ABET Accreditation}

Five Program Directors responded to the accreditation question. Four programs indicated that they were, or were scheduled, to be ABET accredited through the parent institution. An additional program reported that they planned to seek accreditation in the near future. This is not a surprise finding because ABET accreditation is very important for American engineering programs.

\section{Enrollment Management}

Four responses were received for this question, and each Program Director reported a somewhat different form of enrollment management structure. These are summarized in Table 9 below.

Table 9: Enrollment Management And Administration

\begin{tabular}{|c|l|}
\hline Program & \multicolumn{1}{|c|}{ Enrollment Management Structure } \\
\hline A & $\begin{array}{l}\text { Two program coordinators from the parent institution supervise the overall program. The satellite institution } \\
\text { coordinates with the parent institution through these coordinators. The enrollment management office on the } \\
\text { satellite campus handles students during their first year. The satellite program also has a Department Chair } \\
\text { that plays a role in the program administration. }\end{array}$ \\
\hline B & $\begin{array}{l}\text { The parent and satellite campus both enroll students for the program. The registrar's offices at both } \\
\text { institutions maintain copies of student records. Program has a full-time Director housed at the parent } \\
\text { institution. }\end{array}$ \\
\hline E & $\begin{array}{l}\text { A Program Director at the satellite campus coordinates with Deans and Chairs at the satellite campus. The } \\
\text { Program Director also maintains contact with the Dean of Engineering at the parent institution. }\end{array}$ \\
\hline $\begin{array}{l}\text { A Program Director from the parent institution is stationed at the satellite institution. Coordination is done at } \\
\text { the Dean's level with the satellite institution and at the Associate Provost level at the parent institution. } \\
\text { Department Chairs at the parent institution supervise the satellite program for their specific engineering } \\
\text { discipline. Students are initially admitted to the satellite program and then after approximately 3 semesters } \\
\text { apply for admission to the parent program as a special category student in the satellite program. The } \\
\text { registrar's offices at both institutions maintain copies of student records. Degree is awarded by the parent } \\
\text { institution. }\end{array}$ \\
\hline
\end{tabular}

Although unique in some details, the administrative structure in all of the cooperative engineering programs is somewhat similar. All have program directors or coordinators that are housed at either the satellite or parent institution. These administrators coordinate with chairs, deans, and/or associate provosts at the satellite and/or the parent institution.

\section{Scholarships}

Again, representatives from four satellite institutions responded to the question regarding the way scholarships are handled in the cooperative program. These results are summarized in Table 10 below. 
Table 10: Scholarships In Cooperative Engineering Programs

\begin{tabular}{|c|c|}
\hline Program & Scholarship Procedures \\
\hline A & $\begin{array}{l}\text { Scholarships given out by the satellite institution. Most scholarships only cover the first two years when the } \\
\text { students are officially registered at the satellite institution. There is also a limited number ( } 25 \text { per year) of } \\
\text { Engineering Scholarships that cover tuition for all four years. This is entirely funded by the satellite } \\
\text { institution. The only other scholarship funding from the parent institution is the occasional (this is rare) } \\
\text { transfer scholarship that might be obtained. }\end{array}$ \\
\hline B & Students pay tuition at the satellite institution and receive scholarships through the satellite institution. \\
\hline $\mathrm{E}$ & $\begin{array}{l}\text { Students in the cooperative engineering program are treated exactly the same as other on-campus students at } \\
\text { the satellite institution. }\end{array}$ \\
\hline $\mathrm{D}$ & $\begin{array}{l}\text { Students receive scholarships from the satellite institution the first two years. Students then apply for transfer } \\
\text { scholarships from the parent institution for the last two years. }\end{array}$ \\
\hline
\end{tabular}

It appears that most of the responding cooperative engineering programs handle scholarships through the satellite institution.

Billing

When asked about how tuition is handled in the cooperative engineering programs, the responses, summarized in Table 11, indicate that in almost all cases tuition is handled through the satellite program.

Table 11: Tuition Procedure

\begin{tabular}{|c|l|}
\hline Program & \multicolumn{1}{c|}{ Tuition procedure } \\
\hline A & $\begin{array}{l}\text { The students are billed for all four years through the satellite school. In their first two years they pay the } \\
\text { satellite institution rates and the last two years they pay tuition based on the rates for the parent institution. In } \\
\text { all cases the students pay through the satellite institution and then the funds are forwarded to the parent } \\
\text { institution. }\end{array}$ \\
\hline B & $\begin{array}{l}\text { Students use the satellite school billing system and pay tuition and fees there. However, occasional fines and } \\
\text { fees encountered by the parent institution are paid directly to the parent institution. }\end{array}$ \\
\hline E & $\begin{array}{l}\text { Tuition is handled exactly the same as for other students at the satellite institution. The satellite institution } \\
\text { then pays the parent institution directly for each student enrolled in the cooperative engineering program. }\end{array}$ \\
\hline D & $\begin{array}{l}\text { Billing for engineering courses is done by the satellite institution. The satellite institution then sends the funds } \\
\text { to the parent institution. The parent institution then reimburses the satellite institution for engineering courses } \\
\text { taught by faculty employed by the satellite institution. }\end{array}$ \\
\hline
\end{tabular}

No response $=3$

\section{Tuition Reimbursement}

The participating institutions were asked to describe how tuition reimbursement, if any, is handled between the parent and satellite institutions. The responses are summarized in Table 12.

Table 12: Tuition Reimbursement Policies

\begin{tabular}{|c|l|}
\hline Program & \multicolumn{1}{|c|}{ Tuition Reimbursement } \\
\hline A & $\begin{array}{l}\text { This is not done. The satellite institution forwards the funds collected for the parent program's classes that } \\
\text { occur on site at the satellite school. }\end{array}$ \\
\hline B & $\begin{array}{l}\text { There is an agreement between the two participating institutions. Tuition is not exchanged. The satellite } \\
\text { institution pays the parent institution as per the agreement. }\end{array}$ \\
\hline E & There is direct tuition payment exchange between the two participating institutions. \\
\hline D & There is tuition reimbursement for courses taught by faculty employed by the satellite institution. \\
\hline
\end{tabular}

No response $=3$

This table shows that a variety of systems are used to distribute the cooperative revenue between the parent and satellite institutions. 


\section{Program Faculty}

The survey asked the respondents to report the percentage of courses in the satellite program that are taught by faculty from the parent institution, faculty at the satellite institution, and by distance instruction from the parent institution. The responses to this question are presented in Table 13.

Table 13: Percentage Of Faculty Participation

\begin{tabular}{|c|c|}
\hline Program & Percentage of Faculty Participation \\
\hline A & $\begin{array}{l}\text { Memorandum of understanding states that faculty participation in the cooperative engineering program should } \\
\text { be } 50 \% \text { by the parent institution and } 50 \% \text { by the satellite institution. This is achieved by having two faculty } \\
\text { members from the parent institution stationed full time at the satellite institution and one to two additional } \\
\text { faculty members from the parent institution regularly commute from the parent institution to the campus of the } \\
\text { satellite program. All of the first two years of the program are taught entirely by faculty from the satellite } \\
\text { institution as well as all social science and humanities courses in the upper level. So the percentage by class } \\
\text { load is approximately } 60 \% \text { by the satellite program and } 40 \% \text { by the parent institution. In addition, about } 20 \% \\
\text { of the engineering classes are taught via distance. }\end{array}$ \\
\hline B & $\begin{array}{l}\text { Only } 4 \% \text { of the courses in the program are taught by faculty in the satellite institution. All other courses are } \\
\text { taught by faculty at the parent institution. No courses are taught via distance. }\end{array}$ \\
\hline $\mathrm{E}$ & $\begin{array}{l}\text { Approximately } 25 \% \text { of all courses in the program are taught via distance from the parent institution and the } \\
\text { remaining } 75 \% \text { are taught by faculty at the satellite institution. }\end{array}$ \\
\hline $\mathrm{D}$ & $\begin{array}{l}\text { The parent and satellite institutions each provide approximately half of the engineering faculty in the satellite } \\
\text { program. The parent institution also provides a full time Program Director stationed at the satellite campus. } \\
\text { The two institutions also have established a distance education link so that some engineering classes, probably } \\
\text { upper division electives, can be offered at the satellite campus via distance. Probably no more than } 10 \% \text { of } \\
\text { the courses in the program would be offered via distance from the parent institution. }\end{array}$ \\
\hline
\end{tabular}

No response $=3$

As the table indicates, each program uses a different combination of parent program faculty, satellite program faculty, and distance education to deliver their specific program.

\section{SUMMARY AND CONCLUSIONS}

Four-year cooperative engineering programs appear to be a relatively new concept in engineering education, but, as shown in this study, an increasing number of such programs are being developed and implemented around the country. One of the most surprising findings is that the majority of students in cooperative programs are full-time, traditional students, who are unable or unwilling to attend an engineering program at a distance of greater than 100 miles from their home. Employment does not appear to be the reason for the geographical constraint. Instead, we suspect that the high cost of room and board is a major factor for students selecting to attend a cooperative engineering program in their area.

Cooperative engineering programs tend to offer degrees in only Civil, Electrical, and Mechanical Engineering, the most popular of the traditional engineering majors. Tuition and scholarships are generally handled by the satellite program, and administration is primarily handled by directors and/or coordinators located at either the satellite or parent campus. These individuals then report to chairs, deans, and/or provost level administrators.

All in all, the cooperative engineering programs investigated in this study appeared to be more similar to than different from each other.

The authors are aware of three other cooperative engineering programs that were established in the past, but in time the cooperative agreement between the two schools was severed. These programs are still in operation but each has now become a stand- alone program. In two of these cases, the satellite institution was part of the same multi-campus university system. As these two satellite programs grew, a decision was made to develop the satellite programs into stand-alone programs. In the third case, disagreements between the parent and satellite programs led 
to the severing of the cooperative agreement and the satellite institution established a stand-alone engineering program.

\section{ACKNOWLEDGEMENT}

The authors wish to acknowledge the support of the College of Natural and Applied Science at Missouri State University for the funds required to conduct and evaluate the survey of cooperative engineering programs.

\section{AUTHOR INFORMATION}

Dr. Robert I. Egbert is Professor of Electrical Engineering at Missouri State University in Springfield, MO and is a participant in the Missouri University of Science and Technology/Missouri State University Collaborative Engineering Program. Dr. Egbert received B.S., M.S. and Ph.D., degrees in Electrical Engineering from Missouri University of Science and Technology (then known as the University of Missouri - Rolla) in 1972, 1973, and 1976, respectively. He was a member of the faculty of the Department of Electrical and Computer Engineering at Wichita State University in Wichita, KS for over 20 years. He has also worked in industry as a consulting engineer. In 2008 he joined the faculty of Missouri State University as the first faculty member in the new cooperative engineering program established between Missouri University of Science and Technology and Missouri State University. Address: Cooperative Engineering Program, Missouri State University, 901 South National Avenue, Springfield, MO 65897: E-mail: REgbert@ missouristate.edu.

Dr. Lorene H. Stone is Professor of Sociology at Missouri State University and serves as the Director of the Center for Social Sciences and Public Policy Research. Dr. Stone received a B.S. in Sociology from Iowa State University in 1975; her M.A. and Ph.D., in Sociology were awarded in 1978 and 1980, respectively, from Washington State University. Prior to her current position, she served as Dean of the College of Humanities and Public Affairs at Missouri State University for seven years and held administrative and faculty positions at Lamar University for seventeen years. E-mail: Lorenestone@ missouristate.edu.

David L. Adams is Assistant Professor of Library Science at Missouri State University in Springfield, MO. Mr. Adams received a B.S in Electronic Engineering Technology in 1987 from the West Virginia University (then known as West Virginia Institute of Technology) and an M.A. in Library and Informational Science from the University of Missouri - Columbia in 1991. Prior to joining Missouri State University in 1997 he has worked in industry as a test engineer and as a technical information specialist at a federal agency research laboratory. E-mail: Davidadams@missouristate.edu.

\section{REFERENCES}

1. Burbank, K. A., G. W. DeSain, and F. M. Tranjan, A New Joint Electrical Engineering Program, 2004 American Society for Engineering Education Annual Conference and Exposition, 2004.

2. Hess, H. L., R. Rinker, R. W. Wall, N. J. Peterson, and K. Belknap, Two-University Cooperation: Paradigm for the Future of Statewide Engineering Education, 1996 American Society for Engineering Education Annual Conference and Exposition, 1996.

3. Thamire, C., and S. Ainane, Collaborative Engineering Programs at Frostburg State University, 2002 American Society for Engineering Education Annual Conference and Exposition, 2002.

4. Wilson, S. S., and M. E. Cambron, Creation of an Assessment Plan for a Project Based Electrical Engineering Program, 2005 American Society for Engineering Education Annual Conference and Exposition, 2005 


\section{APPENDIX A: INSTITUTIONS PARTICIPATING IN THE SURVEY}

The authors wish to extend their appreciation to the following institutions for participating in this survey. Each pair of participating universities is listed.

1. University of Arkansas - Fayetteville and University of Arkansas - Fort Smith

2. Washington University in St. Louis and the University of Missouri-St. Louis

3. Missouri University of Science and Technology and Missouri State University

4. Washington State University and Olympic College

5. University of North Dakota and Benedictine College

6. Georgia Tech University, Georgia Tech Savannah, Georgia Southern University and Savannah State University 


\section{APPENDIX B: LIST OF SURVEY QUESTIONS}

The twenty-six questions listed below were sent to the universities identified as being involved in some type of cooperative engineering program.

1. What are the names of the institutions involved with your cooperative engineering program?

2. In what academic year was your cooperative program implemented?

3. What was the total enrollment in your cooperative engineering program in: 2006-2007? 2007-2008?

2008-2009?

4. What degrees are offered in your cooperative engineering program?

5. What percentage of the students in your program are traditional students, i.e., 18-22 years old?

6. What percentage of the students in your program are non-traditional students, i.e., over 23 years old?

7. What percentage of the students in your program are enrolled full-time?

8. What is the average SAT, ACT, or other national exam score for students in your program? How does this compare to scores from the parent institution?

9. What is the average GPA for both the parent institution and all associated satellite institutions in 20082009 ?

10. What percentage of the students in the cooperative program are geographically bound and live within a 50 mile radius of the satellite institution?

11. What percentage of the students in the cooperative program are geographically bound and live within a 100 mile radius of the satellite institution?

12. What are the graduation rates for both the parent and satellite institutions in 2008-2009?

13. What is the average number of years to complete an engineering degree at the parent and satellite institutions?

14. What percentage of graduates from the satellite program move farther than 50 miles from the satellite institution after receiving their degree?

15. What percentage of graduates from the satellite program move farther than 100 miles from the satellite institution after receiving their degree?

16. What percentage of students in your cooperative program are pursuing a second degree after obtaining a degree in a non-engineering field?

17. What percentage of the students in your cooperative program are pursuing a second degree after having obtained a degree in another engineering area?

18. Is your program ABET accredited? If so, is it accredited independently or through the parent institution?

19. How is enrollment managed at the satellite institution?

20. How are scholarships handled at the satellite institution?

21. How is billing handled at the satellite institution?

22. Is there tuition reimbursement between the parent and satellite institutions? If so, how is it administered?

23. What percentage of the courses in your program are taught by faculty from the parent institution who come to the satellite institution?

24. What percentage of the courses in your program are taught by faculty from the satellite institution?

25. What percentage of the courses in your program are taught by distance from the parent institution?

26. Are you aware of other cooperative engineering programs in the U.S.? Please share these with us. 
NOTES 